\title{
Karakteristik Fisikokimia dan Sensoris Selai Bengkuang (Pachyrhizus Erosus L.) dengan Penambahan Pektin dan Asam Sitrat pada Berbagai Konsentrasi
}

\section{Physicochemical and Sensory Characteristics of Jicama Jam (Pachyrhizus Erosus L.) with the Addition of Pectin and Citric Acid at Various Concentrations}

\author{
Arif Prashadi Santosa ${ }^{1}$, Oetami Dwi Hajoeningtijas ${ }^{2}$, Ismi Noviandita ${ }^{3}$ \\ ${ }^{1,2,3}$ Program Studi Agroteknologi Fakultas Pertanian dan Perikanan, \\ Universitas Muhammadiyah Purwokerto
}

\begin{tabular}{l}
\hline \hline ARTICLE INFO \\
\hline Article history: \\
DOI: \\
10.30595/pspfs.v2i.170 \\
Submitted: \\
July 29, 2021 \\
Accepted: \\
Sept 10, 2021 \\
Published: \\
Nov 10, 2021 \\
\hline
\end{tabular}

Keywords:

Citric Acid, Pectin, Jam, Proximate Test, Sensory Test

\begin{abstract}
This research aimed to figure out the effect of differences in concentration of citric acidand pectin and their interactions on the content of proximate and sensory of jam.The research was conducted using a completely randomized design (CRD) with a factorial pattern consisting of two factors.The first factor was the comparison of thethree levels of citric acid (A) concentration: $1 \%$ (A1), $2 \%$ (A2), and 3\% (A3) of the total ingredients for making jam.The second factor was pectin concentration (P) in 4 levels: $0.83 \%(\mathrm{P} 1), 1.0 \%(\mathrm{P} 2), 1.17 \%(\mathrm{P} 3)$, and $1.34 \%(\mathrm{P} 4)$ of the total ingredients for making jam.The chemical parameters tested included moisture content, fiber content, ash content, and antioxidant, while the physical parameters included $\mathrm{pH}$ and viscosity.The sensory test assessments includedaroma, taste, color, preference, and spreadability.The results indicated that the comparison of the concentration of citric acid (A) had a significant effect on the proximate analysis of the $\mathrm{pH}$ variable; however, it had no significant effect on several other variables:moisture content, crude fiber content, ash content, viscosity, and antioxidant.The results of the sensory test did not significantly affect the variables of aroma, taste, color, preference, and spreadability.In addition, the treatment of pectin (P)concentration ratio had a significant effect toward proximate analysis on water content and viscosity variable, but it had no significant effect on the variables offiber content, ash content, $\mathrm{pH}$, and antioxidant.Meanwhile, the sensory test had a significant effect on the preference variable and had no significant effect on the aroma, taste, color, and spreadibilityvariables. The treatment interactions (AxP) significantly affectedproximate analysis on $\mathrm{pH}$ and viscosity variables.However, it did not affect the variable of water content, fiber content, ash content, and antioxidantsignificantly.The sensory test results hada significant effect onpreference variable.The best treatment wason the use of $1 \%$ citric acid concentration and $0.83 \%$ pectin concentration (A1P1) with $42.63 \%$ water content, $37.54 \%$ fiber content, $0.25 \%$ ash content, $\mathrm{pH}$ of 3.30 , a viscosity of $8.49 \mathrm{cP}$, and an antioxidant of $9.22 \%$.The treatment resulted in the aroma of 3.67 (delicious), taste of 4.67 (delicious), color of 4.00 (yellowish white), preference of 5.00 (likevery much), and spreadability 3.67 (easy).
\end{abstract}

This work is licensed under a Creative Commons Attribution 4.0 International License.

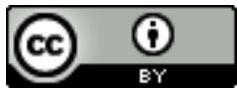




\title{
Corresponding Author:
}

Oetami Dwi Hajoeningtijas

Program Studi Agroteknologi Fakultas Pertanian dan Perikanan

Universitas Muhammadiyah Purwokerto

Email: oetamidwihajoeningtyas@ump.ac.id

\section{PENDAHULUAN}

Selai merupakan produk makanan dengan konsisten gel atau semi padat yang di buat dari bubur buah. Konsistensi gel pada selai di peroleh dari senyawa pektin yang berasal dari buah atau pektin yang ditambahkan dari luar dengan bantuan gula, sukrosa, dan asam (Trisnowati, 2012). Konsumsi selai di Indonesia mengalami peningkatan setiap tahunnya. Salah satu jenis selai yaitu selai bengkuang. Selai ini menggunakan bahan bengkuang untuk menambah kandungan nutrisi di dalam selai. Seperti yang telah kita ketahui, bengkuang dapat digunakan sebagai alternatif dalam pengembangan diversifikasi pangan karena memiliki berbagai zat gizi seperti vitamin C, kalsium, fosfor, dan serat yang sangat dibutuhkan tubuh. Disamping itu bengkuang mengandung oligosakarida (inulin) yang berguna bagi penderita diabetes (Rimbawan dan Nurbayani, 2013). Namun, bengkuang mudah mengalami kerusakan jika disimpan dalam keadaan segar dan untuk meningkatkan umur simpannya perlu alternatif pengolahan menjadi produk baru yang mempunyai nilai ekonomis (Syarif dan Waryono, 2014). Dengan mengolah menjadi selai, diharapkan dapat menghasilkan produk baru dan memberikan nilai tambah, serta memperpanjang umur simpan bengkuang pangan (Dewi et al., 2012).

Syarat yang diperlukan dalam pembuatan selai adalah dengan menambahkan bahan antara lain pektin, asam sitrat, dan gula. Penambahan pektin pada pembuatan selai dilakukan untuk mengatasi masalah gagalnya pembentukkan gel pada proses pembuatan selai yang terbuat dari sayuran maupun buah-buahan yang memiliki kandungan pektin rendah. Sedangkan asam sitrat berfungsi untuk mengentalkan tekstur selai, menurunkan $\mathrm{pH}$, dan menghindari terjadinya pengkristalan gula. Selain pektin dan asam sitrat, terdapat gula yang berfungsi untuk memberikan rasa manis dan sebagai pengawet yaitu apabila penambahan sukrosa pada konsentrasi tinggi akan menghambat pertumbuhan mikroorganisme dengan cara menurunkan aktivitas air dari bahan pangan (Margono, 2000).

\section{METODE PENELITIAN}

\section{Tempat dan Waktu Pelaksanaan}

Penelitian berlangsung selamat empat bulan dan dilaksanakan di Laboratorium Agroteknologi Dasar Fakultas Pertanian, Laboratorium Kimia Analisis Fakultas Farmasi Universitas Muhammadiyah Purwokerto dan Laboratorium Teknologi Pertanian Universitas Jendral Soedirman.

\begin{abstract}
Alat dan Bahan
Alat - alat yang digunakan untuk membuat selai yaitu timbangan analitik merk Sartorius, parutan, pisau, pengaduk kayu, wajan, dandang, baskom, mangkok, sendok, kompor, termometer, toples/jar kaca, tutup toples, cawan porselin, oven, desicator, soxhlet, erlenmeyer, kertas saring whattman 41, spatula, hot plate, pipet volume, beaker glass, batang pengaduk, tanur, $\mathrm{pH}$ meter, Labu takar, gelas piala, alat viscometer manual Brookfield, label, Labu ukur, pipet, spektrofotometer UV-1800 Shimadzu, Plastik mika, label, garpu plastik, kamera, dan borang penelitian

Bahan-bahan yang digunakan untuk membuat selai diantaranya Bengkuang (Pachyrhizus erosus L.),

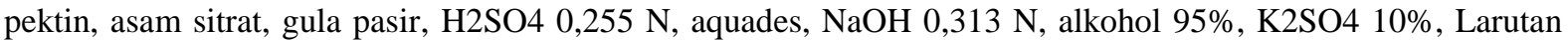
buffer 7,0, aquades, metanol PA 96\%, larutan DPPH 0,1 ml, Sampel selai, roti tawar, biscuit crakers, dan air mineral.
\end{abstract}

\section{Rancangan Penelitian}

Rancangan pada penelitian ini menggunakan Rancangan Acak Lengkap (RAL) dengan pola faktorial dimana terdapat 2 faktor yaitu konsentrasi asam sitrat dan konsentrasi pektin. konsentrasi asam sitrat (A) yaitu A1 (1\%), A2 (2\%), A3 (3\%). Konsentrasi pektin (P) yaitu P1 (0,83\%), P2 (1,0\%), P3 (1,17\%), P4 (1,34\%) Tiap perlakuan diulang sebanyak tiga kali sehingga terdapat 36 kombinasi perlakuan.

\section{Pelaksanaan Penelitian}

Pembuatan selai dilakukan dengan mensortasi bengkuang kemudian dicuci dan diparut lalu menimbang bengkuang sebanyak 150 gram, dan dikukus selama 30 menit. Setelah itu dicampur dengan bahan lainnya seperti gula sebanyak 97,5 gr, asam sitrat dan pektin sesuai dengan perlakuan, kemudian dilakukan pemasakan selama 30 menit dengan suhu $\pm 100^{\circ} \mathrm{C}$. Bengkuang dikemas di jar kaca dan siap untuk untuk dianalisis. 


\section{Variabel Pengamatan}

Analisis proksimat meliputi kadar air (AOAC, 2005), kadar serat kasar (Sudarmadji et al., 2007), kadar abu (Sudarmadji et al., 1997), pH (Muchtadi et al., 2010), viskositas (Manual Labratory Brookfield Viscometer, 2006), dan antioksidan (Sayuti dan Rina, 2015). Analisis sensoris (SNI 01-2346-2006) meliputi aroma, rasa, warna, kesukaan, dan daya oles.

\section{Pengamatan dan Analisis Data}

Selai lalu di uji sensoris dan uji proksimat. Kemudian dianalisis proksimat dan sensoris. Data yang diperoleh dianalisis dengan menggunakan analisis sidik ragam, dan jika terdapat perbedaan yang nyata antar perlakuan dilanjutkan dengan uji DMRT taraf 5\%.

\section{HASIL DAN PEMBAHASAN}

\section{Kadar Air}

Kadar air pada selai sangat penting untuk mengetahui umur simpan selai dari kerusakan mikrobiologi (Ahmadi et al., 2018). Menurut Desrosier (1988), semakin keras gel yang terbentuk maka jumlah air bebas yang terdapat dalam bahan akan berkurang. Hal ini karena pektin akan menggumpal dan membentuk serabut halus yang dapat menahan cairan yang ditentukan oleh banyaknya penambahan pektin. Data kadar air lengkap dapat dilihat pada Tabel 1. Kadar air pada penelitian ini berkisar 35,00- 43,03\% sesuai dengan metode AOAC, 2005.

Tabel 1. Nilai Rata-rata Hasil Analisis data Fisikokimia pada Produk Selai Bengkuang (Pachyrhizus erosus L.) dengan Perlakuan Konsentrasi Asam Sitrat

dan Konsentrasi Pektin

\begin{tabular}{|c|c|c|c|c|c|c|}
\hline Perlakuan & \multicolumn{6}{|c|}{ Variabel Pengamatan } \\
\hline $\begin{array}{l}\text { Konsentrasi } \\
\text { asam sitrat }\end{array}$ & K. Air $(\%)$ & $\begin{array}{c}\text { K. Serat } \\
\text { Kasar }(\%)\end{array}$ & $\begin{array}{c}\text { K. Abu } \\
(\%)\end{array}$ & $\mathrm{pH}$ & $\begin{array}{l}\text { Uji Viskositas } \\
\text { (cP) }\end{array}$ & K. AO (\%) \\
\hline $\mathrm{A} 1$ & $\begin{array}{c}38,80 \pm 4 \\
417\end{array}$ & $\begin{array}{c}37,63 \pm \\
0,117\end{array}$ & $0,25 \pm 0$ & $3,27 \pm 0,180 \mathrm{c}$ & $8,83 \pm 0,425$ & $\begin{array}{c}9,29 \pm \\
0,071\end{array}$ \\
\hline $\mathrm{A} 2$ & $39,30 \pm 3,106$ & $37,63 \pm 0,124$ & $0,25 \pm 0$ & $\begin{array}{c}2,81 \pm 0,143 \\
\mathrm{~b}\end{array}$ & $8,89 \pm 0,424$ & $\begin{array}{r}9,32 \pm \\
0,069\end{array}$ \\
\hline A3 & $39,92 \pm 3,579$ & $37,62 \pm 0,139$ & $0,25 \pm 0$ & $2,56 \pm 0,149 \mathrm{a}$ & $9,01 \pm 0,382$ & $\begin{array}{c}9,48 \pm \\
0,041\end{array}$ \\
\hline Ket & tn & tn & tn & $*$ & tn & tn \\
\hline \multicolumn{7}{|l|}{$\begin{array}{c}\text { Konsentrasi } \\
\text { Pektin }\end{array}$} \\
\hline P1 & $\begin{array}{c}40,72 \pm 3,610 \\
d\end{array}$ & $\begin{array}{c}37,54 \pm \\
0,027\end{array}$ & $0,25 \pm 0$ & $2,85 \pm 0,403$ & $8,51 \pm 0,259 a$ & $\begin{array}{c}9,31 \pm 0 \\
122\end{array}$ \\
\hline $\mathrm{P} 2$ & $\begin{array}{c}40,22 \pm 2,431 \\
\mathrm{c}\end{array}$ & $\begin{array}{c}37,75 \pm \\
0,129\end{array}$ & $0,25 \pm 0$ & $2,86 \pm 0,243$ & $8,67 \pm 0,202 \mathrm{a}$ & $\begin{array}{c}9,38 \pm \\
0,055\end{array}$ \\
\hline P3 & $38,72 \pm 4,854 b$ & $\begin{array}{c}37,56 \pm \\
0,021\end{array}$ & $0,25 \pm 0$ & $2,85 \pm 0,385$ & $9,06 \pm 0,151 b$ & $\begin{array}{c}9,35 \pm \\
0,112\end{array}$ \\
\hline P4 & $37,70 \pm 3,111 \mathrm{a}$ & $\begin{array}{c}37,66 \pm \\
0,134\end{array}$ & $0,25 \pm 0$ & $2,96 \pm 0,338$ & $9,40 \pm 0,213 \mathrm{c}$ & $\begin{array}{c}9,41 \pm \\
0,086\end{array}$ \\
\hline Ket & $*$ & tn & tn & tn & $*$ & $\operatorname{tn}$ \\
\hline
\end{tabular}

Interaksi

Perlakuan

\begin{tabular}{|c|c|c|c|c|c|c|c|}
\hline A1P1 & $42,63 \pm 0,700$ & $\begin{array}{c}37,54 \pm \\
0,032\end{array}$ & $0,25 \pm 0$ & $3,30 \pm 0,100 \mathrm{f}$ & $\begin{array}{l}8,49 \pm 0,425 \\
a b\end{array}$ & $\begin{array}{l}9,22 \\
0,030\end{array}$ & \pm \\
\hline A1P2 & $37,08 \pm 0,420$ & $\begin{array}{c}37,81 \pm \\
0,061\end{array}$ & $0,25 \pm 0$ & $\begin{array}{c}3,15 \pm 0,150 \\
\text { ef }\end{array}$ & $\begin{array}{c}8,48 \pm 0,165 \\
a b\end{array}$ & $\begin{array}{l}9,35 \\
0,036\end{array}$ & \pm \\
\hline A1P3 & $43,03 \pm 2,415$ & $\begin{array}{c}37,55 \pm \\
0,030\end{array}$ & $0,25 \pm 0$ & $3,30 \pm 0,300 \mathrm{f}$ & $\begin{array}{l}9,06 \pm 0,165 \\
\text { de }\end{array}$ & $\begin{array}{l}9,23 \\
0,035\end{array}$ & \pm \\
\hline A1P4 & $36,97 \pm 3,645$ & $\begin{array}{c}37,61 \pm \\
0,020\end{array}$ & $0,25 \pm 0$ & $3,35 \pm 0,150 \mathrm{f}$ & $\begin{array}{l}9,28 \pm 0,160 \\
\text { ef }\end{array}$ & $\begin{array}{l}9,35 \\
0,047\end{array}$ & \pm \\
\hline A2P1 & $37,74 \pm 2,260$ & $\begin{array}{c}37,56 \pm \\
0,025\end{array}$ & $0,25 \pm 0$ & $\begin{array}{c}2,85 \pm 0,150 \\
\text { cd }\end{array}$ & $8,44 \pm 0,195 \mathrm{a}$ & $\begin{array}{l}9,23 \\
0,032\end{array}$ & \pm \\
\hline $\mathrm{A} 2 \mathrm{P} 2$ & $38,70 \pm 3,225$ & $\begin{array}{c}37,58 \pm \\
0,025\end{array}$ & $0,25 \pm 0$ & $2,75 \pm 0,150 \mathrm{bcd}$ & $8,67 \pm 0,110 \mathrm{abc}$ & $\begin{array}{l}9,36 \\
0,042\end{array}$ & \pm \\
\hline A2P3 & $38,15 \pm 3,780$ & $\begin{array}{c}37,56 \pm \\
0,020\end{array}$ & $0,25 \pm 0$ & $2,70 \pm 0,100 \mathrm{~b}$ & $9,04 \pm 0,190$ cde & $\begin{array}{l}9,33 \\
0,020\end{array}$ & \pm \\
\hline
\end{tabular}




\begin{tabular}{|c|c|c|c|c|c|c|c|}
\hline $\mathrm{A} 2 \mathrm{P} 4$ & $42,63 \pm 0,700$ & $\begin{array}{c}37,83 \pm \\
0,066\end{array}$ & $0,25 \pm 0$ & $\begin{array}{c}2,95 \pm 0,050 \\
\text { de }\end{array}$ & $\begin{array}{l}9,43 \pm 0,250 \\
\text { ef }\end{array}$ & $\begin{array}{l}9,37 \\
0,020\end{array}$ & \pm \\
\hline A3P1 & $40,31 \pm 0,310$ & $\begin{array}{c}37,53 \pm \\
0,025\end{array}$ & $0,25 \pm 0$ & $2,40 \pm 0,100 \mathrm{a}$ & $\begin{array}{l}8,59 \pm 0,185 \\
a b\end{array}$ & $\begin{array}{l}9,47 \\
0,030\end{array}$ & \pm \\
\hline A3P2 & $37,33 \pm 0,585$ & $\begin{array}{c}37,85 \pm \\
0,025\end{array}$ & $0,25 \pm 0$ & $2,70 \pm 0,100 \mathrm{bcd}$ & $3,86 \pm 0,140 \mathrm{bcd}$ & $\begin{array}{l}9,44 \\
0,035\end{array}$ & \pm \\
\hline A3P3 & $35,00 \pm 5,000$ & $\begin{array}{c}37,56 \pm \\
0,020\end{array}$ & $0,25 \pm 0$ & $\begin{array}{c}2,55 \pm 0,150 \\
a b\end{array}$ & $\begin{array}{l}9,08 \pm 0,165 \\
\text { de }\end{array}$ & $\begin{array}{l}9,48 \\
0,025\end{array}$ & \pm \\
\hline A3P4 & $42,58 \pm 2,580$ & $\begin{array}{c}37,55 \pm \\
0,026\end{array}$ & $0,25 \pm 0$ & $2,60 \pm 0,100 a b c$ & $9,50 \pm 0,235 \mathrm{f}$ & $\begin{array}{l}9,48 \\
0,045\end{array}$ & \pm \\
\hline Ket & tn & tn & tn & $*$ & $*$ & tn & \\
\hline
\end{tabular}

Keterangan : * Berpengaruh Nyata tn : Tidak Berpengaruh Nyata

\section{Kadar Serat Kasar}

Sumber serat pada selai terdapat pada penggunaan bengkuang. Bengkuang memiliki kandungan serat yang tinggi sebesar 24,78 g. Kadar serat pada penelitian ini yaitu 37,85\% jika dikonversikan untuk satu sajian dalam satu lembar roti sebesar 20 gram mengandung 7,57 gram serat, dengan mengkonsumsi selai dapat memenuhi kebutuhan serat harian sebanyak 25,23\%. Data kadar serat lengkap dapat dilihat pada Tabel 1. Kadar serat menggunakan metode (Sudarmadji et al., 2007).

\section{Kadar Abu}

Menurut Winarno (2006), kadar abu suatu produk pangan berkaitan dengan komponen mineral yang ada pada bahan pangan. Kandungan mineral pada bengkuang meliputi fosfor 18,00 mg, kalsium 15,00 mg, dan besi 0,60 mg. Dan pada selai bengkuang, kandungan mineral hanya terdapat pada bengkuang. Data kadar abu lengkap dapat dilihat pada Tabel 1. Kadar abu pada penelitian ini berkisar sebesar 0,25\% sesuai dengan metode (Sudarmadji et al., 1997).

\section{pH}

Semakin tinggi konsentrasi asam sitrat yang ditambahkan maka semakin rendah nilai pH yang dihasilkan, apabila nilai pH semakin rendah maka selai yang dihasilkan akan semakin asam. Hal ini sesuai dengan pendapat dari Muchtadi (1997), bahwa nilai pH 3,1 - 3,5 merupakan salah satu kondisi optimum pembuatan selai. Penambahan asam sitrat pada selai juga dapat mencegah pertumbuhan mikroba dan sebagai bahan pengawet, dan mencegah terjadinya kristalisasi gula pada selai. pH pada penelitian ini berkisar 2,55- 3,35. Data pH lengkap dapat dilihat pada Tabel 1. Dan mengacu pada metode (Muchtadi et al., 2010).

\section{Viskositas}

Penambahan pektin bepengaruh nyata karena pektin yang ditambahkan ke dalam bahan makanan dapat memantapkan sistem dispersi yang homogen pada makanan serta meningkatkan viskositas bahan dan mengurangi kadar air bahan itu sendiri (Juwita et al., 2014). Data viskositas lengkap dapat dilihat pada Tabel 1. Viskositas pada penelitian ini berkisar 8,44- 9,50 Cp sesuai dengan metode (Manual Labratory Brookfield Viscometer, 2006).

\section{Antioksidan}

Antioksidan pada selai bengkuang ini bersumber pada bengkuang, dimana kandungan vitamin $\mathrm{C}$ yang cukup tinggi, memungkinkan bengkuang digunakan sebagai sumber antioksidan yang potensial untuk menangkal atau menetralisir serangan radikal bebas yang cenderung meningkat dalam tubuh akibat hiperglikemia (stres oksidatif) (Hafiz, 2006). Perbedaan yang tidak berpengaruh nyata karena komposisi bengkuang pada setiap perlakuan setara. Data antioksidan lengkap dapat dilihat pada Tabel 1. Antioksidan pada penelitian ini berkisar 9,22 - 9,48 \% sesuai dengan metode (Sayuti dan Rina, 2015).

\section{Aroma}

Aroma pada selai bengkuang pada penelitian ini cenderung dihasilkan dari aroma buah bengkuang itu sendiri. Menurut Murni et al., (2014), aroma yang terdapat pada suatu bahan pangan ada yang berasal dari sifat alami bahan tersebut dan ada yang berasal dari berbagai macam campuran bahan penyusunnya. Hasil rata-rata nilai aroma yaitu 3,58 dan memiliki aroma sedap sesuai dengan SNI 01-2346-2006. Data aroma lengkap dapat dilihat pada Tabel 2. 
Rasa

Bahan penstabil tidak memberikan perubahan rasa karena bahan penstabil tidak memiliki rasa (Indriyati et al., 2006). Asam yang dihasilkan pada asam sitrat untuk selai bengkuang dikatakan dapat dinikmati oleh panelis. Jumlah asam yang digunakan tergantung dari keasaman buah dan $\mathrm{pH}$ akhir selai yang dikehendaki (Desrosier,1988). Hasil rata-rata nilai rasa yaitu 3,69 dan memiliki rasa enak sesuai dengan SNI 01-2346-2006. Data rasa lengkap dapat dilihat pada Tabel 2.

Tabel 2. Nilai Rata-rata Hasil Analisis dan Sensoris pada Produk Selai Bengkuang (Pachyrhizus erosus L.) dengan Perlakuan Konsentrasi Asam Sitrat dan

Konsentrasi Pectin

\begin{tabular}{|c|c|c|c|c|c|}
\hline Perlakuan & \multicolumn{5}{|c|}{ Variabel Pengamatan } \\
\hline $\begin{array}{l}\text { K. Asam } \\
\text { Sitrat }\end{array}$ & Aroma & Rasa & Warna & Kesukaan & Daya Oles \\
\hline $\mathrm{A} 1$ & $3,67 \pm 0,492$ & $3,83 \pm 0,717$ & $3,75 \pm 0,452$ & $3,92 \pm 0,792$ & $3,25 \pm 0,753$ \\
\hline $\mathrm{A} 2$ & $3,58 \pm 0,514$ & $3,42 \pm 0,514$ & $3,58 \pm 0,514$ & $4,25 \pm 0,753$ & $4,00 \pm 0,063$ \\
\hline A3 & $3,50 \pm 0,522$ & $3,83 \pm 0,389$ & $3,50 \pm 0,527$ & $4,00 \pm 0,063$ & $3,42 \pm 0,900$ \\
\hline Ket & tn & tn & tn & tn & tn \\
\hline K. Pektin & & & & & \\
\hline $\mathrm{P} 1$ & $3,22 \pm 0,440$ & $4,00 \pm 0,707$ & $3,67 \pm 0,500$ & $4,67 \pm 0,500 \mathrm{~b}$ & $3,67 \pm 0,500$ \\
\hline $\mathrm{P} 2$ & $3,67 \pm 0,500$ & $3,67 \pm 0,500$ & $3,78 \pm 0,440$ & $3,89 \pm 0,600 \mathrm{a}$ & $3,33 \pm 1,000$ \\
\hline P3 & $3,67 \pm 0,500$ & $3,67 \pm 0,500$ & $3,22 \pm 0,300$ & $4,11 \pm 0,781 \mathrm{ab}$ & $3,89 \pm 0,781$ \\
\hline $\mathrm{P} 4$ & $3,78 \pm 0,440$ & $3,44 \pm 0,527$ & $3,78 \pm 0,440$ & $3,56 \pm 0,527 \mathrm{~b}$ & $3,33 \pm 0,866$ \\
\hline Ket & tn & tn & tn & $*$ & tn \\
\hline $\begin{array}{c}\text { Interaksi } \\
\text { Perlakuan }\end{array}$ & & & & & \\
\hline A1P1 & $3,67 \pm 0,577$ & $4,67 \pm 0,577$ & $4,00 \pm 0$ & $5,00 \pm 0 \mathrm{c}$ & $3,67 \pm 0,577$ \\
\hline A1P2 & $3,33 \pm 0,577$ & $3,67 \pm 0,577$ & $4,00 \pm 0$ & $3,67 \pm 0,577 \mathrm{ab}$ & $3,67 \pm 0,577$ \\
\hline A1P3 & $3,67 \pm 0,577$ & $3,33 \pm 0,577$ & $3,33 \pm 0,577$ & $3,67 \pm 0,577 \mathrm{ab}$ & $3,33 \pm 0,577$ \\
\hline A1P4 & $4,00 \pm 0$ & $3,67 \pm 0,577$ & $3,67 \pm 0,577$ & $3,33 \pm 0,577$ a & $2,33 \pm 0,577$ \\
\hline $\mathrm{A} 2 \mathrm{P} 1$ & $3,00 \pm 0$ & $3,33 \pm 0,577$ & $3,67 \pm 0,577$ & $4,67 \pm 0,577 b c$ & $3,67 \pm 0,577$ \\
\hline $\mathrm{A} 2 \mathrm{P} 2$ & $4,00 \pm 0$ & $3,67 \pm 0,577$ & $3,33 \pm 0,577$ & $4,33 \pm 0,577 \mathrm{abc}$ & $4,00 \pm 0$ \\
\hline $\mathrm{A} 2 \mathrm{P} 3$ & $3,67 \pm 0,577$ & $3,67 \pm 0,577$ & $3,33 \pm 0,577$ & $4,67 \pm 0,577 \mathrm{bc}$ & $4,67 \pm 0,577$ \\
\hline $\mathrm{A} 2 \mathrm{P} 4$ & $3,67 \pm 0,577$ & $3,00 \pm 0$ & $4,00 \pm 0$ & $3,33 \pm 0,577 \mathrm{a}$ & $3,67 \pm 0,577$ \\
\hline A3P1 & $3,00 \pm 0$ & $4,00 \pm 0$ & $3,33 \pm 0,577$ & $4,33 \pm 0,577 \mathrm{abc}$ & $3,67 \pm 0,577$ \\
\hline $\mathrm{A} 3 \mathrm{P} 2$ & $3,67 \pm 0,577$ & $3,67 \pm 0$ & $4,00 \pm 0$ & $3,67 \pm 0,577 \mathrm{ab}$ & $2,33 \pm 0,577$ \\
\hline A3P3 & $3,67 \pm 0,577$ & $4,00 \pm 0$ & $3,00 \pm 0$ & $4,00 \pm 0,577 \mathrm{abc}$ & $3,67 \pm 0,577$ \\
\hline $\mathrm{A} 3 \mathrm{P} 4$ & $3,67 \pm 0,577$ & $3,67 \pm 0,577$ & $3,67 \pm 0,577$ & $4,00 \pm 0 a b c$ & $4,00 \pm 0$ \\
\hline Ket & tn & tn & tn & $*$ & tn \\
\hline
\end{tabular}

Keterangan : * Berpengaruh Nyata tn : Tidak Berpengaruh Nyata

\section{Warna}

Warna yang dihasilkan selai dipengaruhi oleh bahan yang digunakan pada pembuatan selai salah satunya yaitu gula. Semakin tinggi gula yang ditambahkan maka semakin coklat warna selai yang dihasilkan. Pada penelitian ini rata-rata nilai warna yaitu 3,61 dan memiliki warna putih kekuningan sesuai dengan SNI 01-23462006. Hal ini dikarenakan pemberian gula pada selai bengkuang memiliki komposisi yang sama. Hasil Data warna lengkap dapat dilihat pada Tabel 2.

\section{Kesukaan}

Selai dengan konsentrasi pektin yang lebih rendah memiliki tekstur selai lembut dan tidak menimbulkan hardness atau kekerasan. Semakin banyak penambahan pektin maka hardness selai cenderung semakin meningkat (Mandagi et al., 2015). Panelis lebih menyukai selai dengan konsentrasi pektin rendah karena tingkat kekerasan yang rendah dibandingkan dengan konsentrasi pektin yang tinggi yaitu 5,00 dengan nilai sangat suka sesuai dengan SNI 01-2346-2006. Data kesukaan lengkap dapat dilihat pada Tabel 2.

\section{Daya Oles}

Perbandingan jumlah pektin, gula, dan asam sitrat dalam selai sangat penting dalam pembentukan gel. Pembentukan gel yang baik menjadikan tingkat kekentalan tertentu sehingga daya oles selai terhadap selai akan bagus merata. Rata-rata nilai daya oles yaitu 3,55 dengan kategori mudah sesuai dengan SNI 01-2346-2006. Data daya oles lengkap dapat dilihat pada Tabel 2. 


\section{KESIMPULAN}

Perlakuan konsentrasi asam sitrat berpengaruh nyata terhadap variabel $\mathrm{pH}$, serta tidak berpengaruh nyata pada variabel kadar air, kadar serat kasar, kadar abu, viskositas, antioksidan, aroma, rasa, warna, kesukaan dan daya oles. Sementara itu perlakuan konsentrasi pektin berpengaruh nyata terhadap variabel kadar air, viskositas, dan kesukaan. Namun tidak berpengaruh nyata pada variabel kadar serat kasar, kadar abu, $\mathrm{pH}$, antioksidan, aroma, rasa, warna, dan daya oles. Interaksi konsentrasi asam sitrat dan konsentrasi pektin berpengaruh nyata pada variabel $\mathrm{pH}$, viskositas, dan kesukaan. Tidak berpengaruh nyata pada variabel kadar air, kadar serat kasar, kadar abu, antioksidan, aroma, rasa, warna, dan daya oles. Perlakuan yang terbaik penggunaan konsentrasi asam sitrat $1 \%$ dan konsentrasi pektin $0,83 \%$ (A1P1).

\section{DAFTAR PUSTAKA}

Ahmadi, D.N., Nurwantoro, Antonius, H. 2018. Karakteristik Fisik dan Daya Oles Selai Kolang-Kaling yang Dibuat Melalui Substitusi Pektin dengan Modified Cassava Flour (MOCAF) sebagai Bahan Pengental. Jurnal Teknologi Pangan 2(1) 1-7.

Association of Analytical Communities (AOAC). 2005. Official Methods of Analysis (18 Edn). Association of Official Analytic Chemist Inc Mayland. Washington D.C. 49 Pp.

Badan Standarisasi Nasional. 2006. SNI 01-2346-2006: Petunjuk Pengujian Organoleptik dan atau Sensoris. Jakarta: Badan Standarisasi Nasional. $23 \mathrm{hlm}$.

Desrosier. 1988. Teknologi Pengawetan Pangan. Penerjemah M Muljohardjo. Jakarta: Universitas Indonesia Press.

Dewi, N.S., Parnanto, N.H.R., Ridwan A. 2012. Karakteristik sifat fisikokimia tepung bengkuang (Pachyrhizus erosus) dimodifikasi secara asetilasi dengan variasi konsentrasi asam asetat selama perendaman. Jurnal Teknologi Hasil Pertanian. V(2). Agustus 2014. Universitas Sebelas Maret. Surakarta.

Hafiz, R. 2006. Pengaruh Pemberian Minyak Jinten Hitam Terhadap Mofologi Spermatozoa Mencit Diabetes Melltius Yang Di Induksi Aloksan. Artikel Karya Tulis llmiah: 1-25.

Indriyati, Lucia Indrarti, dan Elsy Rahimi. 2006. Pengaruh Carboxymethyl Cellulose (CMC) dan Gliserol Terhadap Sifat Mekanik Lapisan Tipis Komposit Bakterial Selulosa Vol. 8, No. 1, Oktober 2006, Jurnal Sains Materi Indonesia ISSN : 1411-1098 hal :40-44.

Juwita, A.P.K., Yamlen, P.V.Y., Edy, H.J. 2014. Formulasi Cream Ekstrak Etanol Daun Lamun (Syringodium isoetifolium. Program studi Farmasi FMIPA UNSRAT Manado. Jurnal Ilmiah Farmasi: Paracon.

Mandagi. M.S., Purwandari U., Hidayati D. 2015. Analisis Pengaruh Suhu, Waktu, Pektin dan Gula terhadaop Warna dan Tekstur Leather Guava (Psidium Guajava L) Menggunakan Metode RSM (Response Surface Methodology). Jurnal Teknologi Industri Pertanian, 1 - 15.

Margono, T. 2000. Selai dan Jeli. Jakarta: Penerbit Grasindo.

Muchtadi. T.R. 1997. Petunjuk Laboratorium: Teknologi Proses Pengolahan Pangan. Bogor: Pusat Antar Universitas Pangan dan Gizi-Institut Pertanian Bogor..

Muchtadi, T. R, Ayustaningwarno, F dan Sugiyono. 2010. Ilmu Pengetahuan Bahan Pangan. Bandung: Penerbit Alfabeta.

Murni, T., Herawati, N., Rahmayuni. 2014. Evaluasi Mutu Kukis yang Disubstitusi Tepung Sukun (Artocarpus communis) Berbasis Minyak Sawit Merah (MSM), Tepung Tempe, dan Tepung Udang Rebon (Acetes erythraeus). Jurnal Online Mahasiswa, 1 (1).

Rimbawan dan R. Nurbayani. 2013. Nilai Indeks Glikemik Produk Olahan Gembili (Dioscoreaesculenta). Institut Pertanian Bogor. Fakultas Ekologi Manusia. Departemen Gizi Masyarakat. Jurnal Gizi dan Pangan, 8(2): 145-150.

Sayuti, K. Rina Yenrina. 2005. Antioksidan Alami dan Sintetik. Padang: Andalas University Press.

Sudarmadji, S, B. Haryono dan Suhardi. 1997. Prosedur Analisa untuk Bahan Makanan dan Pertanian. Yogyakarta: Penerbit Liberty.

Sudarmadji, S, B. Haryono dan Suhardi 2007. Analisa Bahan Makanan dan Pertanian. Yogyakarta: Penerbit Liberty. 
Syarif, W., dan Waryono. 2014. Pelatihan kewirausahaan pengolahan bengkuang sebagai upaya peningkatan keterampilan dan ekonomi keluarga. Prosiding Konsensi Nasional Asosiasi Pendidikan Teknologi dan Kejuruan (APTEKINDO) ke 7. FPTK Universitas Pendidikan Indonesia Bandung.

Trisnowati, Nurlaila. 2012. Pembuatan Selai Apel (Malus sylvestris mill).Tugas Akhir D -3, Surakarta: Fakultas Pertanian Universitas Sebelas Maret.

Winarno, F. G. 2006. Kimia Pangan dan Gizi. Jakarta: Gramedia Pustaka Utama. 